УДК $883.08^{\prime} 1$

Н. Є. Коломієць, Н. В. Яременко

\title{
ХУДОЖНС ОСМИСЛЕННЯ ЖІНОЧОЇ ДОЛІ В ПОЕТИЧНИХ ТВОРАХ Б. ГРІНЧЕНКА
}

Коломієць Н. Є., Яременко Н. В. Художнє осмислення жіночої долі в поетичних творах Б. Грінченка.

Статтю присвячено актуальній проблемі дослідження своєрідності художньопоетичного осмислення жіночої долі в ліриці Б. Грінченко. Жіночий образ є смисловим центром ряду творів поета. Соціально-психологічні аспекти характеру жінки представлені в системі ліричних персонажів, через ліричне «я», ліричного 
героя, героя «ролевої» лірики. Значна увага приділена віддзеркаленню специфіки епохи в авторській художній концепції особи жінки.

Ключові слова: лірика, соціальна характеристика, психічні стани і процеси.

Коломоец Н. Е., Яременко Н. В. Художественное осмысление женской судьбы в поэтических произведения Б. Гринченко.

Статья посвящена актуальной проблеме исследования своеобразия художественнопоэтического осмысления женской судьбы в лирике Б. Гринченко. Женский образ является смысловым центром ряда произведений поэта. Социально-психологические аспекты характера женщины представлены в системе лирических персонажей, через лирическое «я», лирического героя, героя «ролевой» лирики. Значительное внимание уделено отражению специфики эпохи в авторской художественной концепции личности женщины.

Ключевые слова: лирика, социальная характеристика, психические состояния и процессы.

Kolomoets NE, Jaremenko NV. Art judgment of women's fate in the poetic works of B.Grinchenko.

Article is devoted to the problem of the study of artistic originality and poetic interpretation of women's fate in the lyrics B. Grinchenko. Female character is the semantic center of a number of works of the poet. Social and psychological aspects of the character representation of women in the lyrical character, through the lyrical «I», the lyrical hero, hero «role « of the lyrics. Considerable attention is paid to the specifics of the reflection period in the author's artistic conception of a woman.

Key words: lyrics, social characteristics, mental states and processes.

У ліричних творах Б. Грінченко неодноразово звертався до теми понівеченої жіночої долі. Ідучи за традицією Т. Шевченка, жіночому образу він відводив особливе місце в поетичній спадщині. Жінка була найбільш знедолена в суспільстві, де панував визиск, за своєю природою вона була більш емоційною, тому гостро сприймала суспільні негаразди. Це давало змогу поету-лірику висловити своє ставлення до зображуваного. Гуманістичний потенціал цих творів виявляється в рідкісному за своєю співчутливістю ставленні до знедоленої жінки. Низка жіночих образів змальовується в ліричних творах Б. Д. Грінченка («Мати», «І молилася я, й сподівалася я...», «Матері», «Удові» та інші).

Мотив жіночої самотності, марності життя без кохання висвітлено в образі покірливої жінки-героїні рольової лірики «I молилася я, й сподівалася...». У прагненні до щастя проходить усе життя самотньої жінки: I молилася я, й сподівалася я, Чи не гляне хоч раз любо доля моя. I минали літа, дожидала ї̈, Та даремні були сподівання мої. Не діждалася я... [1, с. 7].

Слова-синоніми «молилася», «сподівалася», «дожидала» в такому разі служать для характеристики різних відтінків одного й того ж явища, для передачі інтенсивності внутрішньої, психічної дії, різноманітності їі проявів, розкривають душевний стан жінки, iї затамовані переживання. Цей образ 
приваблює лагідністю душевних порухів, внутрішньою чистотою. Образ жінки узагальнено-умовний, без виразних індивідуально-особистісних рис. 3 вірша ми дізнаємося, що лірична героїня, від імені якої ведеться оповідь, на порозі старості: «На роботі тяжкій звікувала життя» [1, с. 7]. Автор вживає слово «звікувала», яке за експресивно-смисловими відтінками ближче до слова «проіснувала», «змарнувала», ніж до слова «прожила». Не зазначається у творі і рід занять жінки, лише епітети «тяжкая» до слів «робота» і «праця» визначають особливості сприйняття їх самою жінкою, бо вони не приносили радості, а все життя поставали для неї непосильною ношею. У вірші $є$ портретні деталі, одна 3 них передається сталим народнопісенним епітетом «очі карі». Але якщо в народній поезії цей епітет вживали на позначення дівочої краси, то Б. Грінченко метафоричним висловом «сліпнуть од сліз очі карі» передає відчуття нестерпного болю, безвиході, яке приходить до людини, коли втрачено всі надії на гармонію 3 дійсністю. Епітет «стан недужий» дає змогу відтінити руйнівний вплив на здоров'я жінки непосильної виснажливої праці. Драматичне нагнітання в тексті створюють епітети «даремні сподівання», «пустка німа», «роботі тяжкій», «праця тяжка», «стан недужий», указуючи на соціальну безвихідь особистості в антигуманному суспільстві.

Причини драматизму життя цієї жінки, на думку автора, криються в соціальній природі класового суспільства, у якому наявнене пригнічення особистості. Кінцеве узагальнення сповнене глибоко осмисленого переживання героїні. Нагромадження однорідних додатків «долі», «родини», «дружини», повтор слова «нема» сприяють драматичному посиленню інтонаційного руху. Антитеза «Світ широкий усім, а мені він тюрма» $\epsilon$ загальним висновком твору. Героїня не має ні родинного затишку через свою бідність, ні соціального захисту. Доля самотньої жінки викликає глибоке співчуття, змушує задуматися над причинами, які призводять людину до такого відчаю, адже, виходячи з загальнолюдських ідеалів, людина народжена для щастя. Але, як показує Б. Грінченко, у тогочасній дійсності людина не мала права навіть на сімейне щастя через те, що панували антигуманні суспільні умови життя.

У вірші «Удові» поет звертається до знедоленої вдови, яка з малими дітками залишилася сама після смерті чоловіка. У звертаннях до персонажа автор виражає своє ставлення до нього: співпереживаючи, спонукає «За їм не ридай, не вбивайся, небого...», «Не плач же, небого, по йому гіркими. Ти краще б за себе ридала...» [1, с. 23]); емоційно коментує й оцінює події «Він $з$ мукою, з горем розстався тяжкими, А ти їх ще більше придбала!..» [1, с. 23]). У поезії «Матері» лірична оповідь звернена до персонажа. Саме такий вид оповіді, на думку В. Смілянської, передає «значно вищий ступінь емоційної перейнятості автора долею своїх героїв» [3, с. 172], ніж звичайна пряма розповідь чи опис. 
У ліриці письменника образ матері постає як образ найсвятішої, найніжнішої жінки на світі. Драматична материнська доля зображена в поезії «Матері». 3 твору постає образ жінки-страдниці, яка все своє життя присвятила синові, у нього вклала всю свою душу. Одним із важливих психологічних прийомів $є$ контраст між жахливою реальністю та нездійсненними мріями жінки. Уся художня система твору несе на собі відбиток цього протиставлення. Поезія відзначається високим ступенем узагальнення. Автор вказує лише на похилий вік жінки: «життя ти доживаєш» та на те, що вона живе удвох із сином. Це дає змогу глибше передати соціально-психологічний iї портрет. Твір наскрізно пройнятий смутком, який виникає зі співвідношення переживання 3 поетичним ідеалом. У тексті оповідь ведеться від імені ліричного «я» сина. Манера оповіді перегукується з Шевченківською («Якби ви знали, паничі»). Оповідь від імені дорослого сина підкреслює драматизм життєвої долі, мати не змогла виплекати синові щастя, йому судилося через суспільні негаразди жити «із лихом, 3 горем вкупі»: Мене малого доглядала І сповивала, і кохала, Малому виглядала долю Й благала бога, щэоб ніколи Не довелось мені на світі Із лихом, з горем вкупі жити [1, с. 4].

У цих рядках сконцентровано мрії про добро, щасливе життя, що виключає можливість існування чогось злого, недоброго; мрії про неминучість підтримки з боку сил небесних, які, за народним уявленням, завжди відкликаються на щирі звертання людей. Підбір дієслів «доглядала», «сповивала», «кохала», що постають як синонімічний ряд, дає можливість передати ніжність материнських почуттів, прагнення добра і щастя для дитини. Автор через сприйняття сина передає чисте, ніжне почуття материнської любові. Устремління до ідеалу відчутне в усьому: і в тому, як у найважчі хвилини життя мати благала малому синові щасливої долі, і в тому, як, доживаючи свій вік, вона ще чекає кращих часів: В журбі життя ти доживаєш, $A$ все ти долі виглядаєш Мені і мною ти живеш I днів ясних в бездоллі ждеш [1, с. 4].

Мріям про щасливе майбутнє, на які вказує інверсія «днів ясних», протистоять гіркі реалії життя, та доля, яка судилася їй, як і багатьом іншим знедоленим жінкам - це «в журбі життя», «бездолля». Неймовірно важкі умови життя не знівечили моральні принципи жінки, не вбили надії на краще прийдешне. Самосвідомість цієї жінки сповнена почуттям покірливості. Подібна ідеалізація незлобливості та лагідності народних низів спирається на реальну сторону народного самопізнання тієї епохи, зумовленого соціальним тиском пануючих верств і безпорадності маленьких людей, що не можуть протидіяти цьому.

Одним із ліричних персонажів поезії «Мати» також виступає знедолена мати. На відміну від попередньо розглянутого твору («Матері»), у якому майже вся увага поета сконцентрована на передачі ๑ С. Н. Є. Коломієць, Н. В. Яременко, 2013.- 567- 
почуттів і внутрішніх переживань жінки, у цьому вірші автор змальовує певні деталі побуту, що допомагають розкрити соціальний стан ліричного персонажа. Предметні деталі змальованого інтер'єру мають відчутну часову, соціальну забарвленість, у них відтворено особливості життя суспільних низів. Соціальне становище жінки передається через описову деталь, зокрема, у творі згадуються такі реалії щоденного життя, як: домашній лаштунок - «каганчик», «стіл та лави коло стін», «піл», «рядно»; процеси праці - «прядка торохтить», «пряде бездольна мати», «довгу нитку витягає». Г. Поспєлов у монографії «Лірика» відзначав, що «предмети побутового оточення - їх наявність та склад, їх багатство чи бідність, дбайливість чи недбалість у ставленні до речей, їх розташування, порядок чи безлад i т. ін. - завжди так чи так несуть на собі відбиток того життя, яке ведуть люди у своєму житлі, завжди відображають тією чи тією мірою і соціальні властивості, і культурний рівень, і психологічний склад» [2, с. 149] власників помешкання, представників певної епохи, певної соціальної групи. Епітети «вбогій хаті», «вбогі стіни», «вбого, тихо у тій хаті», «вбога мати» емоційно підкреслюють соціальну злиденність, затамоване горе родини. Автор вживає здрібнілу лексему «каганчик» на означення селянського убозтва.

У творі змальовано образ жінки, яка залишилася вдовою з малим сином i змушена виконувати непосильну роботу, що іiі повністю фізично виснажує, обезкровлює. Це підкреслюють слова «наболілі» руки, «ледве можучи робить», «в хворих грудях заниває»: Наболілими руками Ледве можучи робить, Довгу нитку витягає Вбога мати удова; В хворих грудях заниває, Як під гнітом голова, - Та не кидає: на сина Заробляти треба їй... [1, с. 37-38].

Б. Грінченко порушує у творі загальнолюдські проблеми - моральний обов’язок батьків перед дітьми. Своєю тяжкою працею мати сподівається заробити на прожиток, що дасть змогу утримувати сина.

На відміну від поезії «Матері», словесна образність твору «Мати» майже не містить ніяких емоційно-виражальних елементів, здебільшого є номінативною. Рядки пов'язані певною перелічувальною інтонацією, а інверсії («сплять великі і малі», «в хаті вбогій», «заблима він», «не лягла ще досі мати», «хлоп’я, рядном укрите», «спить хлоп’я») та епітети («хаті вбогій», «вбогі стіни», «наболілими руками», «вбога мати», «хворих грудях», «бездольна мати» та ін.) підсилюють драматичне нагнітання, акцентують на соціальній знедоленості ліричних персонажів.

Авторське ставлення до жінок виявляється у звертаннях до них «небого» («Удові»); співчутливих інтонаціях «бідна ненька», «гіркі сльози», «Ти краще б за себе ридала» («Удові»), «В журбі життя ти доживаєш», «днів ясних в бездоллі ждеш» («Матері)»; протиставленнях «Він з мукою, з горем розстався тяжкими, А ти їх ще більше придбала!..» («Удові»), «І пряде бездольна мати, син, щасливий снами, спить» («Мати»). Для жіночих образів 
поезії Б. Грінченка властиве драматичне сприйняття соціальної дійсності. Немає жодного вірша, з якого не струменіла б авторська соціальна емоція. Дійсність у сприйнятті автора - жахлива, вона змушує страждати фізично, тому лейтмотивом його ліричної спадщини є люті муки, журба, зболіле серце, побите, сточене, зотлілеє, співи-ридання, пісня сумна, гніт тяжкий, лихо, сльози, прокльони, горе, світ цей - темрява темна, тюрма, неволя тяжка, самотина, нудьга, дні похмурі.

Більшість образів жінок-матерів потерпають в умовах існуючої дійсності, вони журяться, плачуть, страждають, їхні мрії маревом ідуть у небуття, суспільство, засноване на експлуатації людини людиною, витягує життєдайні сили 3 людей, роблячи їх життя марним, пропащим. Ці соціальні процеси хвилюють самого автора, завдають болю його вразливому «зболілому» серцю. Це стимулює авторський пошук шляхів, що виведуть людину з демократичних кіл із тенет соціальної приреченості.

Б. Грінченко підводить читача до висновків широкого змісту - про антигуманну сутність усього суспільного ладу. Поет показує, як жорстокі умови життя нівечать долі чуйних, прекрасних душею жінок. I їх страждання автор трактує як загальнонародне лихо, породжене тиском соціального устрою, суспільними умовами. В основі змісту цих творів лежить контрастне протиставлення мрій ліричних персонажів реаліям життя. Загальнолюдські ідеали любові, рівності, материнської самопожертви заради щастя дитини постають із творів митця як найвища моральна й соціальна цінність.

\section{Література}

1. Грінченко Б. Д. Твори : у 2-х т. / Б. Д. Грінченко. - К. : Вид-во АН УРСР, 1963. Т. 1 : Поезії. Оповідання. -603 с.

2. Поспелов Г. Н. Лирика / Г. Н. Поспелов. - М. : Изд-во Москов. ун-та, 1976. - 208 с.

3. Смілянська В. Л. «Святим огненним словом...» Тарас Шевченко : поетика / В. Л. Смілянська. - К. : Дніпро, 1990. - 290 с. 